\title{
Article
}

\section{Student science publishing: an exploratory study of undergraduate science research journals and popular science magazines in the US and Europe}

\begin{abstract}
Mico Tatalovic
Science magazines have an important role in disseminating scientific knowledge into the public sphere and in discussing the broader scope affected by scientific research such as technology, ethics and politics. Student-run science magazines afford opportunities for future scientists, communicators, politicians and others to practice communicating science. The ability to translate 'scientese' into a jargon-free discussion is rarely easy: it requires practice, and student magazines may provide good practice ground for undergraduate and graduate science students wishing to improve their communication skills.
\end{abstract}

Publishing research articles in peer-reviewed journals is also an acquired skill and many undergraduate students lack the knowledge, confidence and skills to publish their work. Once again, practice is available in student peer-reviewed journals. These are popular in the USA and have recently become more popular in Europe, especially at the UK universities. These journals are usually aimed at undergraduates interested in staying in academia, and give them the opportunity to publish their research while learning about science publishing and science research at the same time.

In this paper I report on the exploratory results of an Internet search made for student science journals and magazines in the USA and Europe. I describe these publications and discuss their role in the communication of science and science education whilst acknowledging the current lack of academic studies about such publications. I also note the recent rise in their popularity in Europe and predict an increase in such publications in the near future.

\section{Introduction}

Scientific journals are (alongside conferences) the main way of communicating research results to the scientific community [4]. Peer review guarantees a certain level of quality and reliability in the published articles [4], and so scientists, policy makers and the general public generally have a high level of trust in findings published in such journals. With many and diverse scientific disciplines there are also many diverse scientific journals: a whole industry of scientific publishing exists and journals are one of the cornerstone institutions of the modern science [4]. But one interesting development in the field of science journals that the general scientific community may have easily missed is the proliferation of undergraduate student research journals (although occasionally they get mentioned in prestigious journals and newspapers such as Science [1] and the New York Times [2], and also in smaller local newspapers [3]). With university science degrees becoming less didactic and ever more practical, encouraging handson research experience and independent research projects, more and more undergraduates have the opportunity to conduct their own experiments and investigations [5]. Some of these students have realized that finishing the research and analysing the data is not the end for a professional scientist; the results have to be written up and published in a peer-reviewed journal. Whereas universities usually require a write-up of the student research project in the form of a dissertation, closer to a real-world scenario is a write-up in the form of a research paper. But most undergraduates do not have enough time to do sufficient research to collect enough novel data to be published in professional journal. This is why undergraduate research journals exist: they are designed for publishing the best undergraduate research whilst keeping in mind the junior level of such research. These journals come in two basic forms: journals started by students and journals started by senior faculty members or university departments. In 
both cases the idea is to provide space for keen undergraduates to publish their work and experience the peer-review process. One exception to this, that I found, is the Student Journal of Health Sciences, a journal from Sweden which publishes abstracts from research papers written as a part of the degree, rather than out of students' own incentive and interest.

Whereas journals focus mainly on the benefits to the students who write the papers and enhance communication among science students and scientists, student popular-science magazines may benefit students and the general public alike and enhance communication between the science community and the non-scientist public. Journal articles are written mainly by students wishing to pursue careers in science research, while popular science articles are written mainly by science students thinking of moving into science communication careers. In fact, some of these magazines are produced by students who are actually pursuing degrees in science communication, such as Faculty Science Magazine, cleverly abbreviated to FSM (echoing the popular men's magazine FHM), produced by the undergraduate students on the BSc in Science and Media course at the University of Plymouth, UK, or I, Science produced by students studying for the MSc in Science Communication at Imperial College, London.

\section{Methods}

I performed an Internet search for student science research journals and popular science magazines, the results of which are summarized in Tables 1, 2 and 3. I used following phrases: 'student/undergraduate science magazine', 'student/undergraduate science journal', 'student/undergraduate research magazine/journal' and also the links within the websites of the publications I found in this way. This biased my sample to publications with websites only. Due to a language barrier my focus was biased towards English language journals or those that could be found by searching in English or were linked to English language websites. Although undergraduate research journals that publish science alongside humanities topics also exist, I excluded these from the analysis and focused only on publications that specialise in publishing science and maths since main interest of this article was student science publishing and publications specialised for this purpose and not student publishing in general. The results and discussion are based on this sample and I acknowledge that the exact quantitative results may have been different if all existing student science publications could have been included.

The aims of student science publications have been compiled from the lists of aims that can be found on many of the publication's websites: whilst not all publications list all of the aims, I have presented all the aims that various individual publications listed, many of which overlapped for several publications. In an attempt to get an insider's perspective I have also interviewed two editors of such publications, one from a journal and one from a magazine, chosen randomly from the list of publications (tables 1,2 and 3). A further, more in depth case-study analysis could provide more accurate picture of students' experiences though. This study is merely an initial, exploratory study of student science publishing aiming to raise awareness of such publications and encourage future research on this, so far neglected area.

\section{Results}

The search revealed 35 journals, 24 of which were based in the USA, 7 in the UK, 2 in Croatia, 1 in France, and 1 in Sweden. There were substantial differences in age and size of the publications and perhaps future studies should attempt to further classify these publications according to age/tradition and size. However, in this first exploratory study all student peer-reviewed journals are classed together as such regardless of their age or size. Fourteen of these were published online only, of which 7 in the US, 5 in the UK, 1 in France, and 1 in Sweden. Two of the journals accepted international contributions. Three had already ceased publication. One published work of university scholars only, one used abstracts from papers that were an obligatory part of the course and one published review papers only.

The ages of the journals ranged from 0-78 years, with a median age of 8 years (mean 12). All of the journals published at least once a year, most of them twice a year, and none more than 4 times a year. None of the European journals published more than twice a year. Being online-only did not appear to affect the number of issues per year. The number of pages in the journals ranged from 4 to 381 with a mean of 83 (median 52). The number of projects published in a single issue varied from 1 to 21 (mean and median 8). 
Most journals focused on biosciences [11] or natural sciences in general [9], with some focusing on psychology [4], maths [3], medicine [2], physics [2], earth sciences [2], chemistry [1] or bioethics [1].

I found 12 popular science magazines: 6 in the UK, 4 in the USA, and 2 in Croatia. All were published in print, and 11 published additionally online. Two published international contributions. Two have ceased publication. The age of the magazines spanned from 0-114, with a median of 8 years (mean 23). These magazines published at least once a year with a maximum of 12 issues per year (median 3 , mean 4). The number of pages in the magazines ranged from 12 to 88 with a median of 34 (mean 44). Most magazines published articles from all sciences [8], with some focusing on medicine [3] or biology [1].

Most journals had no subsections within the issues; those that did had one or more sections named 'news', 'interviews', 'research articles', 'review articles', 'summaries' or 'reports'. All of the magazines had subsections and usually had a larger number of more diverse subsections named 'news' or 'briefs', 'focus', 'features', 'commentaries', 'opinion', 'book reviews', 'student affairs', 'reviews', 'interviews', 'actualities', 'letters', 'life', 'education' and more.

\section{Name}

Saltman Quarterly: Undergraduate Biological Research Publication Journal of Undergraduate Chemistry Research

Journal of Science and Health at the University of Alabama (JOSHUA)

Catalyst: Rice Undergraduate Science Review

MarSci

Journal of Undergraduate Research The Morhead Journal Electronic Journal of Applicable Mathematics Journal of Undergraduate Study and Independent Research

MIT Undergraduate Research Journal (MURJ)

\section{Undergraduate Math Journal}

Discovery: Undergraduate

Research Journal

Journal of Undergraduate Research

Journal of Young Investigators

Princeton Bioethics Journal

Journal of Psychological Inquiry

Psi Chi Journal of Undergraduate Research

Berkeley Scientific

Furman University Electronic

Journal of Undergraduate

Mathematics (FUEJUM)

Modern Psychological Studies

The Journal of Undergraduate

Sciences

The UCLA Undergraduate Science Journal

Journal of Undergraduate Research

\section{Age Subject}

4 Biology

6 Chemistry

6 Life sciences Natural sciences

6 and engineering

6 Marine sciences

7 Science

7 Mathematics

7 Science

8 Biosciences

8 Mathematics Agriculture and

8 life sciences

9 Science

10 Science

10 Bioethics

12 Psychology

12 Psychology

12 Science

13 Mathematics

15 Psychology

16 Science

21 Science

27 Physics

\section{Institution}

University of California, San Diego Yes

Virginia Military Institute $\quad$ Yes

University of Alabama $\quad$ Yes

Rice University $\quad$ Yes

University of South Carolina No

U.S. Department of Energy Yes

Morhead State University No

independent No

Massachusetts Institute of

Technology Yes

Rose-Hulman Institute of

Technology No

University of Arkansas $\quad$ Yes

University of Florida Yes

independent No

Princeton University Yes

Morningsite College Yes

Psi Chi: The National Honor

Society of Psychology Yes

University of California,

Berkeley Yes

Furman University electronic journal of undergraduate mathematics

No

University of Tennessee at

Chattanooga Yes

Harvard University Yes

University of California, Los

Angeles Yes

Society of Physics and the No 
of Physics

The Journal of Psychology and the Behavioural Sciences BIOS-a Quarterly Journal of Undergraduate Biology
Sigma Phi Society

54 Psychology

Fairleigh Dickinson University

Montgomery College
Yes

Yes

Table 1. Undergraduate Science Research Journals in the USA.

\begin{tabular}{|c|c|c|c|c|c|}
\hline \multirow[t]{2}{*}{$\begin{array}{l}\text { Name } \\
\text { Biosciences Horizons }\end{array}$} & Age & Subject & Institution & Country & $\begin{array}{l}\text { Print } \\
\text { issue } \\
\text { No }\end{array}$ \\
\hline & 0 & Biosciences & Oxford Journals & UK & \\
\hline & & & University of & & Yes \\
\hline BlueSci journal & 0 & Science & Cambridge & UK & \\
\hline $\begin{array}{l}\text { Biosciences Undergraduate Research } \\
\text { at Nottingham (BURN) }\end{array}$ & 2 & Biosciences & $\begin{array}{l}\text { University of } \\
\text { Nottingham }\end{array}$ & UK & No \\
\hline SEPS Undergraduate Research & & & University & & No \\
\hline Journal (SURJ) & 2 & Physics & $\begin{array}{l}\text { Surrey } \\
\text { University }\end{array}$ & UK & No \\
\hline Earth and E-nvironment & 3 & Earth sciences & $\begin{array}{l}\text { Leeds } \\
\text { University }\end{array}$ & UK & No \\
\hline Biolog-e & 5 & Biosciences & $\begin{array}{l}\text { Leeds } \\
\text { University }\end{array}$ & UK & Yes \\
\hline Origin & 7 & Biosciences & $\begin{array}{l}\text { Chester } \\
\text { University }\end{array}$ & UK & No \\
\hline Biologos & 7 & Biosciences & $\begin{array}{l}\text { Rennes } \\
\text { Croatian }\end{array}$ & France & Yes \\
\hline studentCMJ & 7 & Medicine & $\begin{array}{l}\text { Medical Journal } \\
\text { Linkoping }\end{array}$ & Croatia & No \\
\hline Student Journal of Health Sciences & 10 & Health sciences & $\begin{array}{l}\text { University } \\
\text { University of }\end{array}$ & Sweden & Yes \\
\hline Ekscentar & 10 & Earth sciences & Zagreb & Croatia & \\
\hline
\end{tabular}

Table 2. Undergraduate Science Research Journals in Europe.

Name
EuSci
Bang!
Faculty Science Magazine (FSM)
I, Science
BlueSci
Triple Helix
innovation: the Princeton Journal of
Science and Technology
In Vivo
studentBMJ
studentJAMA
Medicinar
Yale Scientific

$\begin{array}{rll}\text { Age } & \text { Institution } & \text { Country } \\ 0 & \text { University of Edinburgh } & \text { UK } \\ 1 & \text { University of Oxford } & \text { UK } \\ 2 & \text { University of Plymouth } & \text { UK } \\ 3 & \text { Imperial College } & \text { UK } \\ 4 & \text { University of Cambridge } & \text { UK } \\ 8 & \text { Many } & \text { International } \\ & & \\ 8 & \text { Princeton University } & \text { USA } \\ 12 & \text { University of Zagreb } & \text { Croatia } \\ 13 & \text { British Medical Journal } & \text { UK } \\ & \text { Journal of the American } & \\ 33 & \text { Medical Association } & \text { USA } \\ 90 & \text { University of Zagreb } & \text { Croatia } \\ 114 & \text { Yale University } & \text { USA }\end{array}$

Table 3. Student popular-science magazines in the USA and Europe. 


\section{Discussion}

\section{Aims of student science publications}

Most of these journals have similar missions or purposes and state these on their websites. These missions are as follows:

1) Allow students to experience the peer-review process

2) Teach students how to conduct a science research project in its entirety, including writing-up and publishing results as a research paper

3) Showcase the quality and high standard of undergraduate research at the institution

4) Acknowledge the students' hard work

5) Provide students with the opportunity to publish early in their career, a valuable, enjoyable experience that can also help them to find a postgraduate course, internship or a job as it gives information to the employer about the skills and enthusiasm of such students

6) Provide pupils and younger students with an idea of the standard of research they can aim for at the institution

For example, Origin, a journal of bioscience at the University of Chester, UK states:

"Publication of results is the natural, concluding stage of any successful research project and serves as a reward for the student researcher as well as passing the knowledge gained from the researcher's efforts to a wider audience. For example, many of the student projects undertaken address questions of local or regional importance. Frequently students develop research ideas that build on previous undergraduate, or graduate-level studies. This can develop a rich body of knowledge within a discipline by concentrated focus on, for example, a site, a taxon or an issue." [6]

Another biosciences journal, BURN, at the University of Nottingham, UK, states:

"The School of Biosciences forges strong links between research and teaching, at every level of study. Each student carries out a project lasting a calendar year. It gives them an opportunity to take part in real research and to experience science at the front line, finding out new things and thinking about important problems and ideas.

The aim of BURN has been to bring this element of undergraduate work to public view in a professional and relevant way. The students represented here have risen to the challenges of doing rigorous research and presenting their work to a wider audience. Their articles show the distance they have travelled during their studies. They also demonstrate the inquiry and critical thinking skills that have been developed. As graduates, they will be able to exploit these valuable skills in their careers, whether they continue in science or whatever path they may chose.

...BURN exemplifies the integration of learning and research in the real world of bioscience." [7]

\section{Educational benefits to the students}

Students who get involved with such forms of publishing usually benefit hugely from it, says Dr. Alison Fletcher, lecturer and editor of Origin, at the University of Chester, UK (personal communication). Laura Campochiaro, a student editor of Journal of Young Investigators, an online international journal says:

"I have had a very positive experience working for JYI. I first joined the JYI staff as an Associate Editor in May 2006 and became the Editor in Chief in July 2007. As an Associate Editor, I learned a great deal about the process of scientific publication, including the proper mechanics of scientific writing and how peer revision functions. As Editor in Chief, I have gained managerial and teamwork skills, while becoming ever more experienced with all aspects of scientific publication.

The primary reason I joined JYI was that I desired to go beyond basic bench work research and participate in the next step in scientific research, publication. As an undergraduate, there is often ample opportunity to work in a laboratory, but less opportunity to submit or review manuscripts. JYI seeks to resolve this problem and, in my opinion, has done so quite successfully!" 
She also reports on the students that get involved in the production of such journals:

"JYI only publishes articles by undergraduate students and is entirely run by undergraduate students. As such, a variety of students get involved, whose interests range from conducting original research, participating in the editing and revision process of scientific publication, and running the corporate side of the journal in terms of finances, public and internal relations, and website design and management. The Journal is read by a wide range of people, including students of all levels, professors, and the general public." (personal communication)

Thomas Kluywer, editor-in-chief of the Cambridge chapter of the Triple Helix magazine says:

"It's fairly time consuming, but it is rewarding - I'm looking forward to seeing 'my' issue in print (of course, most of the credit is due to the writers and subeditors, but I'll still be proud). A career in scientific publishing is one option I'm considering, so I'm getting useful experience. That's not why I do it, though--the primary reason is simply that it interests me." (personal communication)

Undergraduate research is seen as crucial part of university training in the US. Indeed, the National Conferences of Undergraduate Teaching sees undergraduate research as "the pedagogy for the $21 \mathrm{st}$ century" [5]. Several recent studies seem to support the importance of research in undergraduate learning in that students who engage in such research acquire various skills and benefit from both short- and longterm gains [5]. However, it is questionable how helpful the existence of undergraduate science journals is to advancement of actual research. I searched the Web of Science and Google Scholar but have found no studies examining specifically the educational benefits of publishing in student science journals. Yet most undergraduate journals take it for granted that by engaging with them students will benefit academically. It is interesting to note that many of these journals only publish the best undergraduate projects, as rated by their grade (e.g. 1st class or distinction in the UK) or as recommended by their supervisor. Dr. Denis Poinsot, editor-in-chief of Biologos, journal for biosciences at the University of Rennes, France says that only motivated students (5\% or less) go through the trouble of the publication process, although Biologos is there for all of them. He believes that publishing in such journals means hard work and that many students do not publish because it does not bring them any credit towards their degree (personal communication).

Most journals will only accept manuscripts recommended or 'sponsored' by a senior member of the faculty with expertise in the field. For example, the Journal of Undergraduate Research at the University of Florida, USA, only publishes work done by university scholars. As such, these journals are beneficial to the best students and may give them further incentive to stay in the sciences. The readers of such journals are also ensured of the quality of the work because of the high standard required in order to qualify for publication, the supervisors' recommendations and the peer review process. Although most journals appear to showcase undergraduate research to the university but also to wider community, some journals are more concerned with providing a useful summary of course-relevant information for other undergraduates so they do not have to spend hours in the library researching a certain topic but can read about it in the journal. Such is the Catalyst: Rice Undergraduate Science Review journal at Rice University, USA. This may be another important role for undergraduate journals since a recent study shows that undergraduates have difficulties understanding journal articles and rarely use online indexes or e-journals [8]. This study suggests that libraries and faculties should introduce undergraduates to the structure and content of the articles, as well as provide them with tutorials on the publishing process [8]. This is exactly what such journals do by allowing the students to learn about the process by working through it, and they do not usually need to officially involve librarians or faculty.

Peer-review has been discussed a lot recently with questions arising about the need for double-blind peer review and pharmaceutical company Pfizer trying to retrieve for a purpose of a law suit and make public confidential comments on certain papers published in a peer-reviewed journal New England Journal of Medicine [9]. It is crucial for the new generation of scientists and policy makers to understand the peer-review process and its implications if they are to successfully engage in such discussions in the future. They can do this by actively engaging in peer-review (for example as practicing scientists), and student publications allow them to do this at a very early stage of their career. They also allow those who might decide to switch careers and cease being involved in peer-review to experience it and learn about it first-hand while at university [7]. Undergraduate journals provide an opportunity for students to get involved and experience the intricacies of peer-review for themselves rather than just reading about it in 
literature. Some scientists also complain about the level of literacy of science students and the difficulty these students have in expressing themselves in a clear and understandable way when writing about their research [10]. Some suggest science undergraduates should be trained to write as part of their course [10]. Yet, student journals and magazines offer training by allowing students to write in a way they will be expected to write in when they graduate.

\section{Student science publications as recent arrivals to science communication field}

Student science journals seem to be more abundant and better established in the USA than in Europe; America is the "Eldorado of undergraduate journals" says Dr. Denis Poinsot, editor of Biologos (personal communication). All of the European journals from this sample have been established in the past 10 years or less. This recent proliferation of such journals seems to be a trend, especially in the UK, where two new journals are being launched in 2008, Biosciences Horizons and BlueSci journal, and most were established in the last five years. With positive feedback from journals in the USA and with an increasing number of students going through the process of publishing in such journals we can expect even more student science journals to be established in the UK and perhaps around Europe in the coming years.

Popular science magazines may also benefit the general public by making scientific ideas and research interesting and visually appealing to people who have no expertise in science. The production of such magazines might not always be as academically rewarding for aspiring scientists as publishing research journals, which may explain why there were fewer student science magazines than journals in my search. Some science students decide that they do not enjoy research and choose to swap the laboratory bench for working in the science media. One of the main routes into jobs in science media is via getting experience and getting published [11] and this is where student publications may be helpful to those students. With an increasing number of economic, medical and even religious issues that have scientific background (such as renewable energy sources, climate change, stem cell research, intelligent design) that need addressing by the modern-day governments and people in general, and yet with declining science literacy [12] or declining number of students interested in science [13] public understanding of and interest in science is very important [12]. This is evident from the fact that several professional courses in science journalism and media have been established in the UK since the early 1990s. Science students in the UK have realized that there has been an increased need for science communication: all of the student popular science magazines in the UK have been established in the past 13 years, and the first course in science media in the UK started 17 years ago at Imperial College, London. Since most jobs in the media are highly competitive, experience with student magazines helps in the transition from a science degree to a job in the media [11]. Some people attempt to start training students in publishing in science journals or magazines even earlier, in high-school; an example of this is Eye on Science: a Student Journal of Science and Technology for high-school students in Canada, or Impulse, a high-school student popularscience magazine at Shrewsbury School, UK.

Most magazines are based at a university and report about science from both that specific university but from further afield as well. However, some are published nationally such as student medical magazines (studentBMJ and studentCMJ) and others internationally with chapters at many different universities in several countries such as The Triple Helix: a global forum for science in society, which is a global student magazine with various chapters at universities in several countries. It began in the USA and recently spread to Europe and Asia. Existing chapters in the UK are at the University of Cambridge, University of Oxford, University College London, London School of Economics and Political Studies and King's College London, with the Cambridge chapter coming out with the first UK issue in spring 2007. This magazine produces online and print issues covering various aspects of science and its influence on society. Interestingly, the print version contains a global section with the best articles from across all the chapters and a local section with the articles written at the topical university. It seems to illustrate the need for more two-way discussions between scientists and the public globally. Thomas Kluywer, editor-in-chief of the Cambridge chapter of the Triple Helix says:

"I think the links between science and society are something that many people are interested in, combined with the chance to be part of a world wide organisation. I do think it's important: a great many of the big issues that the world now faces require science -Global warming or GM crops, to give just two examples. I think there's often a difficulty of understanding between the 
scientists who understand, say, how genetic engineering works, and the people who understand what it costs, what practical benefits it can bring, how public perception affects it, and so forth. We aim to bridge that gap."

\section{Funding}

Student publications are usually available for free. Information about funding is not always disclosed on the websites or publications and so it is difficult to know exactly what main or most common ways of funding are. Where such information is available it seems that student science magazines are usually funded by adverts they sell to relevant advertisers that target student population. For example, BlueSci magazine regularly sells advert space to British Petroleum and American Association for Advancement of Science. Journals seem to mainly depend on grants from various funding bodies that support student research and teaching but also sometimes sell advertising space on the website or in the print issues. Future studies could investigate what the best way of funding such publications is to ensure best experience for students and longevity and quality of the publication.

\section{Further study}

Further studies could attempt to investigate the benefits and costs of engaging with such publications for students. How many of the purported aims do these publications actually fulfill? Are students that publish in such journals more likely to stay in academia or become better scientists or science communicators? Is the experience with these publications really going to be "invaluable to their profession" as some claim [14]? Are they more likely to get better grades? How many students fail at attempts to join or publish in such publications and how does this affect them? Do these publications serve as an unofficial meeting point between the universities and the public? Do they play a significant role in promotion of science outside the universities they are based at? These are just some of the questions that might be worth pursuing in the future. A good starting point might be a comprehensive list of such publications such as the one in the present study (tables 1,2 and 3) or the ones started by the US Council on Undergraduate Research [15] or the Student Press in Europe [16].

\section{Conclusion}

Students in USA and Europe have the opportunity to engage with science publishing and contribute to global discussion of science and society as well as to original scientific research through undergraduate research journals and student popular-science magazines. These journals and magazines exist at several universities and some are published independently or by professional journals. Although engaging with these might be time consuming and hard work for students, the benefits might include acquiring various skills important for scientists and journalists alike, as well as being able to address specific educational issues science students experience at universities [17]. With an increased need for public understanding of science and proliferation of science journalism courses these student journals and magazines are likely to continue to grow in number, especially in Europe where they so far have been sparser than in the USA. Further research is needed to better understand the effects that these publications have on science communication, education and personal career developments of the involved students.

\section{Notes and references}

[1] Online Journal, Bioethics View from the Campus, Science 310 (2005) 1255.

[2] M. Pollack, NOTEBOOK; Online Research Papers, The New York Times Published, February 17th 1999. Available at: http://query.nytimes.com/gst/fullpage.html?res=9C01EFDE113AF934A25751C0A96F958260\&sec $=\&$ spon $=\& s c p=2 \&$ sq $=$ online $\% 20$ research $\% 20$ papers \&st $=$ cse.

[3] C. Menzel, Students Start Science Journal. The Cornell Daily Sun (Online), Published: March 10th 2005. Available at: http://www.thetriplehelix.org/documents/press/DailySun TTH.pdf. 
[4] A. Simonić, Znanost: Najveća Avantura i Izazov Ljudskog Roda. Sveučilište u Rijeci: Rijeka (2001).

[5] National Conferences on Undergraduate Research website, Retrieved 10/03/2008, Available at: http://www.ncur.org/ugresearch.htm.

[6] University of Chester: ORIGIN website, Retrieved 10/03/2008, Available at: http://www.chester.ac.uk/origin/.

[7] University of Nottingham: BURN website, Retrieved 10/03/2008, Available at: http://www.nottingham.ac.uk/burn/.

[8] C. Tenopir et al, Undergraduate Science Students and Electronic Scholarly Journals, ASIST 2003 contributing paper, ASIST 2003 Annual Meeting -- Humanizing Information Technology: From Ideas to Bits and Back (ASIST AM 03 2003), Westin Long Beach, Long Beach, California, October $20-23,2003$.

[9] D. Kennedy,Confidential Review-or Not, Science 319 (2008) 1009.

[10] R. Grant, On the Care and training of students, especially the training, Weblog. The Scientist. 12th March 2008. Nature Network. 14th March 2008. Available at: http://network.nature.com/blogs/user/rpg/2008/03/12/on-the-care-and-training-of-studentsespecially-the-training.

[11] N. Loder, So You Want Be a Science Writer?, association of British Science Writers: London (2002). Available at: http://www.absw.org.uk/Documents/SYWTBASW.pdf.

[12] 'Halt Science Decline in Schools', BBC News website, Retrieved at 10/03/2008 Available at: http://news.bbc.co.uk/2/hi/science/nature/3710906.stm.

[13] Declining interest in science is a concern. CSIRO Media Release, 09/02/2007. Available at: http://www.csiro.au/files/mediarelease/mr2005/helix100.htm

[14] A. Mišak, Citius, Altius, Fortius in 2001, Croatian Medical Journal 42 (2001) 4.

[15] Council on Undergraduate Research website, Retrieved at 10/03/2008 Available at: https://www.cur.org/ugjournal.html.

[16] Student Press in Europe website, Retrieved at 10/03/2008 Available at: http://www.ylioppilaslehti.fi/spine/

[17] J. O’Neil Roach, Making Our Voices Heard: Why Student Journals Are Crucial, Croatian Medical Journal 42 (2001) 67.

\section{Author}

Mico Tatalovic, born in Rijeka, Croatia. BA in Biology from the University of Oxford. Phil Biology at the University of Cambridge. Currently MSc Science Communication student at the Imperial College London. E-mail: mico.tatalovic@keble.oxon.org. 